\title{
Monoteismus v Izraeli a Judsku mezi archeologií, textem a ideologii: Nové impulzy, nová evidence, nové interpretace
}

\section{FILIP ČAPEK ${ }^{*}$}

Mezi ústřední postuláty o vzniku monoteismu ${ }^{1}$ patří představa postupného vývoje, který se započal v jižní Levantě na území starověkého Izraele. Mým cílem je tuto hypotézu s pomocí nejnovějších poznatků z oblasti archeologie, religionistiky a starověkých dějin Izraele postupně chronologicky rozvést a upřesnit. Bude předloženo, že tzv. jižní judská perspektiva pracuje s kritikou kultu v Izraeli jako s ideologickým konstruktem, který zakrývá skutečnost, že počátky monoteismu byly formulovány na severu a že se až později staly prostřednictvím nábožensko-kulturních vlivů a promyšlených vazeb královských dynastií v Izraeli skutečností také v Judsku. Pro porozumění tomuto procesu je nezbytné rozlišovat rovněž mezi oficiálním a neoficiálním kultem a jejich diferenciovanými formami. Zvláštní prostor je věnován centralizaci kultu jako politicko-ekonomickému a kulturnímu fenoménu, který se nepřekrývá s prvními doloženými výskyty důsledně anikonického monoteismu jako takového, protože ten je až důsledkem komplexní reflexe a konstituování nové národní a náboženské identity po kolapsu Judského království v roce 587/6 př. n. 1 .

\footnotetext{
* Tato studie je výsledkem badatelské činnosti podporované Grantovou agenturou České republiky v rámci grantu GA ČR 19-06582S ,Transformace kultu: Interakce a kontinuita v hraničních oblastech pozdního Kenaanu, Pelišteje, Izraele a Judska v době železné I-IIC i za nimi“.

1 K vymezení pojmu viz Angelika Berlejung, Náboženské dějiny starověkého Izraele, Praha: Vyšehrad 2017, 73-88.
} 


\section{0. století př. n. l.: Temno i nový úsvit}

Vznik monoteismu v jeho raných fázích někteří badatelé hledají v jižní Levantě již v 10. stol. př. n. l., tedy v době reurbanizace, jež nastala po kolapsu systému městských států v závěru mladší doby bronzové na konci 13. a ve 12. stol. př. n. l. $^{2}$ Nová města a nová osídlení v 10. a pak i v 9 . stol. př. n. l. jsou zakládána často na půdorysu starších sídel, ale o vzniku teritoriálního státu ve sledované oblasti nelze ještě hovořit. ${ }^{3}$ Tvrzení, že již tehdy bylo náboženství soustředěno na výlučný kult jednoho božstva, navíc $\mathrm{v}$ jednom $\mathrm{k}$ tomu vyhrazenému centru s chrámem, je nepřesné. Neodpovídá existujícímu archeologickému dokladovému materiálu ani kritické analýze starověkých, a to zvláště starozákonních (jakkoli ne výlučně), textů. Je zřetelné, že pro možnou existenci monoteismu nemáme doklady ani v hmotné kultuře nepísemné povahy, ani v textech samotných. Zcela stranou je nezbytné ponechat biblické texty líčící retrospektivně formou zakládajícího mýtu ideál Sjednoceného království existujícího v 10. stol. př. n. 1. se středem v Jeruzalémě a jahvistickým kultem provozovaným v tamním „Šalomounově“ chrámu. Zde lze jen odkázat k referenční literatuře. Ta, pokud je psána s kritickým odstupem, jednoznačně dokumentuje, že je to právě prvoplánové čtení biblických textů, co stále vrací do hry výrazně předčasné dějinné zasazení monoteismu jako takového. ${ }^{4}$ Pro dokreslení skutečné náboženské situace ve starověkém Jeruzalémě lze stručně zmínit, že ve stratu 14 (je datováno do rané fáze doby železné IIA, tj. do 10. stol. př. n. 1.) ve Městě Davidově byly v roce 1981 nalezeny v sektoru $\mathrm{G}$ mezi jinými kultickými předměty také bronzová pěst $\mathrm{z}$ velké sošky Baala a kultický stojan pravděpodobně s reliéfem téhož božstva, obojí v samotném středu města. ${ }^{5}$

Písemné doklady o monoteismu v téže době nejsou k dispozici. Z malého množství existujících textů z 10. stol. př. n. 1. se žádný nedotýká náboženské tematiky. Tyto texty, psané povětšinou raně alfabetickým, respek-

2 Přehledově k tomu viz Eric H. Cline, 1177 př. Kr.: Zhroucení civilizace a invaze mořských národi̊, trans. Ruth J. Weiniger - Kateřina Zerzánová, Praha: Vyšehrad 2018.

$3 \mathrm{~K}$ ranějšímu datování tohoto procesu viz William G. Dever, Beyond the Texts: An Archaeological Portrait of Ancient Israel and Judah, Atlanta, GA: SBL Press 2017. Srov. přesvědčivější Gunnar Lehmann - Hermann M. Niemann, „When Did the Shephelah Became Judahite?", Tel Aviv 41/1, 2014, 77-94.

4 Za mnohé viz Reinhard G. Kratz - Hermann Spieckermann (eds.), One God-One Cult - One Nation: Archaeological and Biblical Perspectives, Berlin: Walter de Gruyter 2010.

5 Yigal Shiloh, Excavations at the City of David I, (Qedem 19), Jerusalem: Hebrew University 1984 (viz Fig. 24 včetně rekonstrukce a srovnání s podobnou soškou z oblasti Kanaánu). 
tive fénickým písmem, ${ }^{6}$ jsou velmi stručné (např. Kfar Veradim), některé pouze o několika písmenech anebo bez jednoznačně srozumitelného obsahu (tak např. Izbet Sarta). Dále se jedná o abecedáře (např. Tel Zajit), texty zaobírající se zemědělskou (Gezerský kalendář), ekonomickou (např. nápis z Bét-Šemeše ${ }^{7}$ a Baalův nápis z téhož místa ${ }^{8}$ ) anebo sociálně-právní tematikou (tak Chirbet Qeiyafa9). Žádný z nich nevypovídá více o soudobé náboženské situaci. Pouze poslední z textů lze jistě interpretovat v náboženském kontextu, kde lze předpokládat, že určité božstvo je nejvyšším garantem vymahatelnosti ochrany otroka, vdovy, sirotka a cizince (tyto čtyři kategorie ostrakon zmiňuje) na vladaři (králi). Tento garant nicméně není v textu samotném uveden, čímž je znemožněno přesnější religionistické zařazení. ${ }^{10}$

Rovněž archeologický dokladový materiál, jenž by potvrzoval existenci monoteismu ve sledovaném století, je nanejvýš diskutabilní. Významnými zastánci této interpretační stopy jsou archeologové z Hebrejské univerzity, kteří vedli v letech 2007-2012 výzkum v Chirbet Qeiyafa v oblasti Šefely, kde byla odkryta starověká pevnost osídlená v 10. stol. př. n. 1. Tu identifikovali jako Šaarajim, místo zmiňované v knihách Samuelových (1S 17,52). Jako argument ve prospěch monoteistického založení kultu v této lokalitě, navíc prohlášené za nejstarší doklad existence Judského království, užívají (a) etnickou afiliaci místa $\mathrm{k}$ danému politickému útvaru, (b) absenci vepřových kostí, (c) doložitelný anikonický kult, (d) desakralizaci kultických

$6 \mathrm{~K}$ terminologii, která poukazuje na raně alfabetickou, popř. fénickou provenienci písma, viz Christopher A. Rollston, Writing and Literacy in the World of Ancient Israel: Epigraphic Evidence from the Iron Age, Atlanta, GA: SBL Press 2010, zvl. 19-46, a id., ,Scriptures and Inscriptions: Eighth-Century Israel and Judah in Writing“, in: Jacob L. Wright - Zev I. Farber (eds.), Archaeology and History of Eighth-Century Judah, Atlanta, GA: SBL Press 2018, 457-473.

7 William H. Shea, „A Potential Biblical Connection for the Beth Shemesh Ostracon“, Andrews University Seminary Studies 25/3, 1987, 257-266.

8 P. Kyle McCarter - Shlomo Bunimovitz - Zvi Lederman, ,An Archaic Ba' $l$ Inscription from Tel Beth Shemesh“, Tel Aviv 38/2, 2011, 35-49.

9 Christopher A. Rollston, „The Chirbet Qeiyafa Ostracon: Methodical Musings and Caveats", Tel Aviv 38/1, 2011, 67-82.

10 K celkovému přehledu alfabetického epigrafického materiálu mezi mladší dobou bronzovou a dobou železnou IIA viz zejm. Israel Finkelstein - Benjamin Sass, ,The West Semitic Alphabetic Inscriptions, Late Bronze II to Iron IIA: Archaeological Context, Distribution and Chronology“, Hebrew Bible and Ancient Israel 2/2, 2013, 149-220. 
objektů ${ }^{11}$ a výše uvedené ostrakon, jehož text považují za pozdně kanaánský a zároveň za nejstarší hebrejský nápis. ${ }^{12}$

Většina $\mathrm{z}$ uvedené argumentace je přinejmenším sporná. ${ }^{13}$ Etnická afiliace se odvíjí od konzervativní představy vzniku raných teritoriálních státních útvarů již na počátku 11. a v 10. stol. př. n. 1. K tomu chybí nicméně evidence, jež by potvrdila, že dané místo je centrem většího institučně i vojensky zajištěného politického celku disponujícího úředním aparátem schopným zajistit výběr daní. Dalšími kritérii, která chybí, jsou rozvinutý obchod a centralizované státní náboženství. ${ }^{14}$ Nic takového v daném období ve sledované oblasti nelze doložit. Co lze vysledovat je postupné znovuobnovení některých měst, jako jsou například Bét Šemeš, Tel Bataš, Tel Azeka, anebo zakládání nových, mezi něž patří Chirbet Qeiyafa. Žádné $\mathrm{z}$ nich $\mathrm{v}$ oblasti nedominovalo nad dalšími, anebo se tak dělo velmi krátce a ve velmi omezeném rozsahu i časovém horizontu, ${ }^{15}$ což dokládá výrazně diverzifikovaná podoba kultu, architektonických i keramických tradic

11 Viz Yosef Garfinkel - Saar Ganor, „Site Location and Setting and History of Research“, in: Yosef Garfinkel - Saar Ganor (eds.), Khirbet Qeiyafa I: Excavation Report 2007-2008, Jerusalem: Israel Exploration Society - Institute of Archaeology, Hebrew University 2009, 25-46; Ron Kehati, „Faunal Assemblage“, in: Yosef Garfinkel - Saar Ganor (eds.), Khirbet Qeiyafa I: Excavation Report 2007-2008, Jerusalem: Israel Exploration Society - Institute of Archaeology, Hebrew University 2009, 201-208; Yosef Garfinkel, ,,The Standing Stone near the Western City Gate“, in: Yosef Garfinkel - Saar Ganor (eds.), Khirbet Qeiyafa I: Excavation Report 2007-2008, Jerusalem: Israel Exploration Society - Institute of Archaeology, Hebrew University 2009, 195-200.

12 Haggai Misgav - Yosef Garfinkel - Saar Ganor, „The Ostracon“, in: Yosef Garfinkel - Saar Ganor (eds.), Khirbet Qeiyafa I: Excavation Report 2007-2008, Jerusalem: Israel Exploration Society - Institute of Archaeology, Hebrew University 2009, 243257. Srov. zdrženlivější Ada Yardeni, „Further Observation on the Ostracon“, in: Yosef Garfinkel - Saar Ganor (eds.), Khirbet Qeiyafa I: Excavation Report 2007-2008, Jerusalem: Israel Exploration Society - Institute of Archaeology, Hebrew University 2009, 259-260, který nápis prohlašuje za semitský a možná hebrejský.

13 K té viz Yosef Garfinkel, „Khirbet Qeyiafa in the Shephelah: Data and Interpretations“, in: Silvia Schroer - Stefan Münger (eds.), Khirbet Qeiyafa in the Shephelah, (OBO 282), Fribourg: Academic Press 2017, 5-59; Yosef Garfinkel - Igor Kreimerman Peter Zilberg, Debating Khirbet Qeiyafa: A Fortified City in Judah from the Time of King David, Jerusalem: Israel Exploration Society 2016; Yosef Garfinkel - Katharina Streit - Saar Ganor - Michael G. Hasel, ,State Formation in Judah: Biblical Tradition, Modern Historical Theories, and Radiometric Dates at Khirbet Qeiyafa, Radiocarbon 54/3-4, 2012, 359-369.

$14 \mathrm{~K}$ definici i diskuzi viz Filip Čapek, Archeologie, dějiny a utváření identity starověkého Izraele, Praha: Vyšehrad 2018, 59-65 a 85-88, srov. také Christian Frevel, Geschichte Israels, Stuttgart: Kohlhammer 2016, 93-171.

$15 \mathrm{~K}$ interpretačně velmi složitému vztahu lokalit Tel Bataš a Bét Šemeš viz Filip Čapek, „The Shephelah in the Iron Age I and IIA: A New Survey of the Emergence of the Early Kingdom of Judah“, Oriental Archive 80/3, 2012, 475-504. 
i způsobů běžného života. ${ }^{16}$ Další z argumentů, absence prasečích kostí jako doklad odlišné judské etnicity, byl pro dané období již přesvědčivě překonán ${ }^{17}$ řadou diferenciovaných hypotéz o odlišnosti mezi pelištejskou a pozdně kanaánskou kulturou a velmi složitých interakcích mezi nimi, ${ }^{18}$ v rámci nichž se až později zformovalo nové endogenní etnikum, které by bylo možné označit za judské. ${ }^{19}$ Anachronické je i tvrzení o desakralizaci kultických objektů, zde konkrétně zabudování macevy do zdi jednoho z domů, pokud je tento akt typologicky srovnáván s odstraněním oltáře v Beer Šebě, které proběhlo až v druhé polovině 8. stol. př̀. n. 1. a je interpretováno jako specifický úkon (konzervace) související s centralizací kultu. ${ }^{20}$

\section{9. století př. n. l.: Století, bez kterého nelze nic pochopit}

V tomto století je nezbytné oddělit dva souběžně probíhající procesy, které se liší jak místně, tak co do podoby formování konkrétních náboženských zvyklostí. Zůstaneme-li na jihu, můžeme sledovat, že tamější kult byl velmi rozmanitý a že doklady o monoteistické náboženské praxi až do posledních fází tohoto století chybí. Př́íkladem pestrého náboženského

16 Zde jsou vodítkem např́klad nádoby k běžnému užití, jejichž podoba je určována lokální tradicí.

17 Lidar Sapir-Hen - Meirav Meiri - Israel Finkelstein, „Iron Age Pigs: New Evidence on Their Origin and Role in Forming Identity Boundaries“, Radiocarbon 57/2, 2015, 307 315; Brian Hesse, ,Pig Lovers and Pig Haters: Patterns of Palestinian Pork Production“, Journal of Ethnobiology 10/2, 1990, 195-225; Brian Hesse - Paula Wapnish, „Can Pig Remains be Used for Ethnic Diagnosis in the Ancient Near East", in: Neil Asher Silberman - David Small (eds.), The Archaology of Israel: Constructing the Past, Interpreting the Present, (JSOTSup 237), Sheffield: Sheffield Academic Press 1997, 238-270.

18 K témuž viz Filip Čapek, ,Judah in Transition between Iron Age I and IIA: Khirbet Qeiyafa as a Crossection of Ethnicities and Cultures“, in: Manfred Oeming (ed.), Das Alte Testament im Rahmen der antiken Religionen und Kulturen, Münster: Lit Verlag 2019, 297-327.

19 Srov. Filip Čapek, „Tel Azeka na mapě interakcí v Šefele konce mladší doby bronzové a doby železné I-IIB a otázka vzniku Judského království“, in: Martin Trefný (ed.), Klasické rozhovory - Colloquia classica, Roudnice n/L: Podřipské muzeum Roudnice n/L 2019, 6-17.

20 Kameny z rozloženého obětního oltáře ze strata Beer Šeba III (ca polovina 8. stol. př̀. n. 1.) byly sekundárně užity pro výstavbu skladiště a jako výplň rampy v sídelní fázi Beer Šeba II. K tomu viz David Ussishkin, The Renewed Archaeological Excavations at Lachish (1973-1994) I, II, Tel Aviv: Emery and Claire Yass Publications in Archaeology 2004. Srov. také David R. Moulis, „Hezekiah's Cultic Reforms according to the Archaeological Evidence", in: Oded Lipschits - Filip Čapek (eds.), The Last Century in the History of the Kingdom of Judah: The $7^{\text {th }}$ Century BCE in Archaeological, Historical and Biblical Perspective, Atlanta, GA: SBL Press 2019, 167-180. 
života jsou v současnosti dvě interpretačně nejvytěžovanější místa. Prvním je Tel Moca v údolí Sórek, vzdálená jen šest kilometrů západně od Jeruzaléma, a druhým již zmíněná Chirbet Qeiyafa, položená jižněji v údolí Éla.

V lokalitě Tel Moca byl znovuzahájen archeologický výzkum v roce 2019 pod vedením Institutu archeologie Univerzity Tel Aviv za spoluúčasti Evangelické teologické fakulty Univerzity Karlovy. ${ }^{21}$ Výzkum navazuje na odkryv chrámu typu megaron v letech 2012-2013, kdy byly odhaleny také oltář, favissa (jáma $\mathrm{k}$ ukládání zbytků z obětí) $\mathrm{s}$ množstvím kostí obětovaných zvírat a pódium určené k vystavování kultických objektů. V blízkosti favissy se nalezla figurka koně a dvě antropomorfní figurky, a sice hlavy mužů s čelenkou, které jsou dekorovány podobně jako jinde nalezené pelištejské figurky $\mathrm{z}$ téže doby. ${ }^{22}$ Provedení figurek se liší od plaketových figurek typických pro oblast jižní Levanty. Tím se potvrzuje silný vliv pelištejské kultury a přeneseně i původnějších tradic $\mathrm{z}$ egejské oblasti i ve vnitrozemí později vznikajícího Judského království. ${ }^{23}$ Bez zajímavosti není, že podobná figurka byla nalezena také v Chirbet Qeiyafa. ${ }^{24}$ Jak tyto náboženské artefakty interpretovat a jak vysvětlit jejich distribuci?

Podle Garfinkela, vedoucího kampaně v Chirbet Qeiyafa, který tímto poupravuje své dřívější tvrzení o anikonické praxi, dokládají figurky z obou lokalit první fázi ikonografické tradice v Judsku v 10. stol. př. n. 1. ${ }^{25}$ Božstvo, tvrdí Garfinkel, bylo zobrazováno jako jezdec na koni (ten byl skutečně v Tel Moce nalezen, ale je otázkou, jak souvisí s figurkami ${ }^{26}$ ),

21 Shua Kisilevitz - Oded Lipschits, „Another Temple in Judah! The Tale of Tel Moza“, Biblical Archaeology Review 46/1, 2020, 40-49; Filip Čapek, „Chrám plný otázek: Tel Moca“, Forum 46, 2019, 22-25. Pro webové stránky kampaně viz <https://www.telmoza.org/>, [7. 3. 2020].

22 Viz David Ben-Shlomo, Philistine Iconography: A Wealth of Style and Symbolism, (OBO 241), Fribourg: Academic Press - Göttingen: Vandenhoeck und Ruprecht 2010; id., „Philistine Cult and Religion according to Archaeological Evidence“, Religions 10/2, 2019, 1-28.

23 Shua Kisilevitz, ,The Iron Age IIA Judahite Temple at Tel Moza“, Tel Aviv 42/2, 2015, 147-164.

24 Viz Yosef Garfinkel - Saar Ganor - Michael G. Hasel, Ekevót Dávid Hamelech Beemek Haéla, Tel Aviv: Yedioth Achronoth 2012, 164.

25 Yosef Garfinkel, „,The Iron Age Clay Figurine Head“, in: Yosef Garfinkel - Saar Ganor - Michael G. Hasel - Martin G. Klingbeil (eds.), Khirbet Qeiyafa IV: Excavation Report 2007-2013: Art, Cult, and Epigraphy, Jerusalem: Israel Exploration Society Institute of Archaeology, Hebrew University - Institute of Archaeology, Southern Adventist University 2018, 143-163.

26 Kisilevitz, vedoucí výzkumu v Tel Moce, se domnívá, že jde s největší pravděpodobností o samostatně stojící figurky, protože ,,jsou zakulacené a vyhotovení pramenů vlasů byla věnována velká péče“. Viz S. Kisilevitz, „The Iron Age IIA Judahite Temple at Tel Moza...", 158. 
a jedná se tedy o tzv. ikonickou fázi monoteismu, která byla až později, na konci 9. a v první polovině 8 . stol. př. n. 1., vystř́íána fází anikonickou. ${ }^{27}$ V rámci ní zůstala nicméně uchována ikonografická tradice jezdce s koněm, avšak v menším provedení a pouze se schematickým zachycením hlavy jezdce.

Zvláštní postavení mají v dané diskuzi judské pilířové figurky (dále jen JPF podle angl. Judaean Piller Figurines), které Garfinkel považuje za původně izraelské, tedy pocházející ze severu, a až druhotně judské. Jejich užití na jihu je vysvětlováno trvající touhou místního obyvatelstva po ikonickém zobrazení. Protože jezdec, muž, byl jako božstvo co do zobrazování již zakázán, nahradila jej žena reprezentovaná JPF. Jako druhé vysvětlení Garfinkel nabízí, že výskyt JPF je způsoben masovou migrací Izraelců po pádu Samaří v roce 722 př. n. $1{ }^{28}$ Uvedenou interpretaci je třeba hodnotit kriticky, protože nebere v úvahu (či spíše odmítá) kulturní vazby na Pelišteu, které jsou je přitom prokazatelné. Nejde jenom o figurky nalezené v Chirbet Qeiyafě a Tel Moce, ale také o další doklady ${ }^{29}$ a o skutečnost, že první místo je spíše ještě pozdněkanaánské než judské. ${ }^{30}$ Příliš jednostranná je také prredstava JPF jako importu z Izraele v 8. stol. přr. n. 1 . Většina současného bádání vidí v JPF, jejichž výskyt je doložen již na počátku 9. stol. př. n. 1., na jedné straně judský fenomén, popřípadě jev, kterým se definují hranice Judska a jeho náboženství, na straně druhé pak doklad vzájemného ovlivňování náboženských a ikonografických tradic v kontextu jižní Levanty jako celku (k JPF viz také dále).

Shrneme-li diskuzi o náboženských reáliích z konce 10. a v 9. stol. př. n. 1. na jihu, nic nenasvědčuje existenci či alespoň počátku formování monoteismu jako odlišné podoby náboženské praxe. Chirbet Qeiyafa je pozdněkanaánským městem menšího rozsahu s vlastním svébytným způsobem života $^{31}$ a druhé z míst ve fázi s chrámem, o něco mladší Tel Moca, ${ }^{32}$ je co

27 Srov. Eva Janáčová, „Ikonická a anikonická tradice v náboženství starověkého Izraele“, Religio: Revue pro religionistiku 14/1, 2006, 69-86.

28 K tomu viz Yosef Garfinkel, „The Iron Age Clay Figurine Head...“. Viz také stručný apendix „Petrographic Analysis of the Iron Age Figurine“ (ibid., 158), jejímž autorem je David Ben-Shlomo, který tvrdí, že hlava figurky je nepelištejského původu, protože materiál pochází pravděpodobně z oblasti níže položeného Lakíše.

29 Srov. Shua Kisilevitz - Oded Lipschits, „Another Temple in Judah...“, kteří poukazují na podobnost s figurkami z pelištejského Ašdódu (zde z 11. stol. př. n. 1.) a edómského hlavního města Bosry (9./8. stol. př. n. 1.).

30 Viz David Ben-Shlomo - Erin D. Darby, ,A Study of the Production of Iron Age Clay Figurines from Jerusalem“, Tel Aviv 41/2, 2014, 180-204.

31 Jedním z nejlepších dokladů jsou místní zásobnice s otiskem palce, které se nevyskytují, až na zcela nepatrné výjimky, jinde, a proto lze otisk považovat za hrnčirirskou značku, a nikoli za doklad širší distribuce.

32 Stratigrafie Tel Mocy je zatím předběžná a vychází ze srovnání s keramikou ze strat Jeruzalém 13 a 14 (z druhé uvedené sídelní vrstvy pocházejí artefakty související bud' 
do nálezového celku dokladem existence smíšeného kultu, který vykazuje rovněž pozdněkanaánské a pelištejské vlivy. Pokud nastaly změny, které by bylo možné považovat za zárodky až výrazně později krystalizujícího monoteismu, je třeba se přes Jeruzalém vydat na sever, do Izraele.

Jeruzalém v 9. stol. př. n. l., donedávna považovaný za město nevelkého rozsahu, lokálního významu a téměř bez monumentální architektury, ${ }^{33}$ je nově interpretován jako místo, jež v druhé polovině tohoto století zažívá rozkvět v důsledku silných politicko-ekonomických a kulturních vazeb na Izrael, který prostřednictvím dynastických svazků prosazoval svůj vliv v Jeruzalémě. Silnou a viditelnou provázanost Judska 9. stol. př. n. 1. se severem se zdají potvrzovat nejnovější výsledky výzkumu v Jeruzalémě, mezi něž patři revidované datování zdí a věže zajištujících Gíchonský pramen (angl. Gihon spring tower) ve východní části Davidova města. ${ }^{34}$ Poslední data ze sektorů $\mathrm{C}$ a $\mathrm{H}$ a dále pak i sektoru $\mathrm{E}$ umožňují nahlížet na druhou polovinu 9. stol. př. n. 1. v jiném světle, a sice jako na dobu růstu města včetně budování monumentální architektury. ${ }^{35}$

Doklad o proměnách v Jeruzalémě, a to i náboženských, přinášejí biblické texty. Lze se domnívat, že přestože nejsou vzhledem k událostem, které líčí, synchronní, jejich kritická analýza může poskytnout jiný vhled do dění v Judsku ve sledovaném století. Tím se situace liší od ryze literárního popisu předchozího století, kde se co do rekonstruovatelných dějinných skutečností ocitáme na velmi nezajištěné půdě. ${ }^{36} \mathrm{~V}$ textech knih Královských týkajících se 9. stol. př. n. 1. je zřetelný protiizraelský osten, který má výrazně náboženskou složku. Kromě odsuzování judských panovníků, kteří pocházeli z vládnoucí dynastie Omríovců v Samaří nebo se

s baalistickým kultem, anebo konfrontací s ním; k tomu viz dále). Výsledky absolutního datování zatím nebyly zveřejněny.

33 Srov. Doron Ben-Ami, Jerusalem: Excavations in the Tyropoeon Valley (Givati Parking Lot) I, (IAA Report 52), Jerusalem: Israel Antiquities Authority 2013.

34 Srov. F. Čapek, Archeologie..., 138-139.

35 Joe Uziel - Nahshon Szanton, ,Recent Excavations near the Gihon Spring and Their Reflection on the Character of Iron II Jerusalem“, Tel Aviv 42/2, 2015, 233-250; Yuval Gadot - Joe Uziel, ,,The Monumentality of Iron Age Jerusalem Prior to the $8^{\text {th }}$ Century BCE“, Tel Aviv 44/2, 2017, 123-140; Johanna Regev - Joe Uziel - Nahshon Szanton - Elisabetta Boaretto, ,Absolute Dating of the Gihon Spring Fortifications, Jerusalem“, Radiocarbon 59/4, 2017, 1171-1193.

$36 \mathrm{~K}$ optimistickým rekonstrukcím viz Omer Sergi, „The Emergence of Judah as a Political Entity between Jerusalem and Benjamin“, Zeitschrift des Deutschen Palästina-Vereins 133/1, 2017, 1-23 (hebrejsky 2015); id., „Rethinking Israel and the Kingdom of Saul", in: Oded Lipschits - Yuval Gadot - Matthew J. Adams (eds.), Rethinking Israel: Studies in the History and Archaeology of Ancient Israel in Honor of Israel Finkelstein, Winona Lake, IN: Eisenbrauns 2017, 371-388, a id., ,The United Monarchy and the Kindgom of Jeroboam II in the Story of Absalom and Sheba's Revolt (2Sam 15-20)“, Hebrew Bible and Ancient Israel 6/3, 2017, 329-353. Ke kritice tohoto pohledu viz F. Čapek, Archeologie..., 76-88. 
s ní spř̌iznili sňatkem, ${ }^{37}$ je souběžně nekompromisně odsuzována i jejich náboženská praxe jako ta nejhorší myslitelná. Je jim podsouvána nejen služba Baalovi a nespočtu dalším božstvům, ale i lidské oběti, ${ }^{38}$ o kterých neexistuje jediný archeologický doklad. ${ }^{39}$ Po rozkrytí ideologického kódování těchto textů se nabízí zcela jiné čtení, a sice že to byli právě Omríovci, kdo do Judska přinesl jahvistický kult a zasadil se o jeho rozšíření, ale tato jejich náboženská iniciativa byla záměrně v projudsky laděné historiografii odsunuta do zapomnění a iniciátorem změn se stává až Joáš (835796 př. n. 1.; viz $2 K r$ 11,18). Jakkoli je zpráva o Ataljině (841-835 př. n. 1.) působení v Jeruzalémě kritická, lze se domnívat, že to byla právě ona, kdo „transformoval kult božstva Šalim a kdo přebudoval existující svatyni na jahvistický chrám“40 a kdo je také spoluzodpovědný za rozkvět města víceméně v rozsahu Města Davidova, ale nikoli nad jeho rámec, tak, že by se již dalo počítat s umístěním chrámu na Chrámové hoře. ${ }^{41}$ Uvedená historická rekonstrukce počítá s dřívějším a intenzivnějším nejen ekonomickým, ale i náboženským a kulturním propojením Izraele a Judska, než jaké nabízí tzv. kompromisní model předložený I. Finkelsteinem a zastávaný T. Römerem a řadou dalších. ${ }^{42}$

Co ale dokládá, že byl jahvistický kult praktikován na severu, odkud pak byl přinesen i do Judska? Prvním z dokladů je mocenský vzestup Izraele, v jehož důsledku je politicko-pragmaticky zvolen jeden dominantní

37 Jedná se o Jórama (848-841 př. n. 1.), manžela Atalji, dcery Omríovce Achaba, jeho syna Achazjáše (841 př. n. 1.) a o Atalju (841-835 př. n. 1.), která se podle Druhé knihy Královské 11,1 snaží vyhubit veškeré královské potomstvo v Jeruzalémě.

38 Graeme Auld provokativně, ovšem co do textové analýzy přesvědčivě dokládá, že skupiny baalovských proroků jsou, stejně jako skupiny proroků Ašery, literární invencí, která má svůj ideologický cíl neodpovídající skutečnosti. K tomu viz Graeme Auld, „Righting Israel's Kings“, in: Manfred Oeming - Petr Sláma (eds.), A King Like All the Nations? Kingdoms of Israel and Judah in the Bible and History, Münster: Lit Verlag 2015, 147-158, a id., „Eliah and the Prophets of Baal and of Asherah: Towards a Discussion of ,No Prophets? “, in: Ranfrid I. Thelle - Terje Stordalen - Mervyn E. J. Richardson (eds.), New Perspectives on Prophecy and History: Essays in Honour of Hans M. Barstad, (VTSup X), Leiden: Brill 2015, 7-16.

39 K historickému šablonování v knihách Královských zaměřenému na srovnání hodnocení judských králů Achaze, Chizkijáše, Menašeho a Jóšijáše viz F. Čapek, Archeologie..., 179-208.

40 Ernst A. Knauf, 1 Könige 1-14, Freiburg: Herder Verlag 2016, 261.

41 Tak Alon De Groot - Hillel Geva, ,Nonetheless - The City of David Is Not on the Temple Mount", in: Eyal Baruch - Avraham Faust (eds.), New Studies on Jerusalem XXI, Ramat Gan: Bar-Illan University 2015, 7-24 (hebrejsky).

42 Zejm. Israel Finkelstein, „Migration of Israelites into Judah after 720 BCE: An Answer and an Update“, Zeitschrift für die alttestamentliche Wissenschaft 127/2, 2015, 188206. Srov. také Nadav Na'aman, ,Dismissing the Myth of a Flood of Israelite Refugees in the Late Eight Century BCE“, Zeitschrift für die alttestamentliche Wissenschaft 126/1, 2014, 1-14. 
„národní“ bůh, jímž se stává bůh Jahve.. ${ }^{43}$ Dalším dokladem jsou texty elíšovského cyklu ( $2 K r$ 2-13), které ukazují, byt z důvodů pozdějších redakcí jeruzalémských písařských kruhů formou via negativa, že jahvistický kult představoval dominantní náboženství Izraele a že byl soustředěn do hlavních center Izraele, zvláště do Samaří, ${ }^{44}$ ale i dalších míst, jakými byly Tel Dan, Bétel, Penúel a pak také Megiddo. ${ }^{45}$ To samozřejmě neznamená, že šlo o kult výhradně monoteistický a že v Izraeli nebyla předmětem úcty i další božstva. ${ }^{46}$ Garanty kultu byli vládnoucí Omríovci a po nich Nimšíovci, jedna z větví předchozí dynastie pravděpodobně pocházející z Tel Rehóv, ${ }^{47}$ místa ukázkového prolínání vlivů pozdněkanaánské a ,izraelské“ kultury (analogický jev je rozpoznatelný na jihu v Bét Šemeši a v Tel Bataš). Jakkoli texty elíšovského cyklu nepocházejí přímo z druhé poloviny 9. stol. př̀. n. 1., protože byly nejdřive tradovány ústně, lze se domnívat, že uchovávají stopy dějinných a náboženských skutečností daného století. $^{48}$

Dủležitým zdrojem o podobě náboženství Izraele je Méšova stéla z druhé poloviny 9. stol. př. n. 1., sepsaná v moábštině. Zde se líčí, jak moábský král Méša (přibližně 860-825 př. n. 1.) válčil s Izraelem, který za Omríovců Achaba (875-853 př. n. 1.), Achazjáše (853-852 př. n. 1.) a Jórama (852-841 př. n. 1.) okupoval jeho království. ${ }^{49}$ Izrael podle sdělení stély utlačuje Moáb po mnoho dní, ale po změně na trůnu v Samaří dochází k oslabení jeho politického vlivu v Zajordání. Pravděpodobně Jóram se

43 Srov. A. Berlejung, Náboženské dějiny..., 158-181.

$44 \mathrm{~K}$ pozdější představě centralizace viz Israel Finkelstein, Zapomenuté království: Archeologie a dějiny severního Izraele, Praha: Vyšehrad 2016, 143-145 a 169-171.

$45 \mathrm{~K}$ náboženské stigmatizaci těchto míst viz Angelika Berlejung, ,Twisting Traditions: Programmatic Absense-Theology for the Northern Kingdom in 1 Kgs 12:26-33* (the ,Sin of Jeroboam")“", Journal of Northwest Semitic Languages 35/2, 2009, 1-42.

46 Zde je otázkou, jak a zda lze v biblických látkách, at již prorocké, či narativní povahy, oddělit permanentní hodnocení praxe Izraele jako baalistické od skutečných poměrů na severu. $\mathrm{Z}$ textově-kritické analýzy stěžejních míst, jako jsou např. $A m 8,14,1 K r 12$,2830 anebo $1 K r$ 16,32, je možné usuzovat, že původní jahvistický kontext byl přepsán a nahrazen z ideologických důvodů kontextem baalistickým, aby byl Izrael politicky i nábožensky stigmatizován. Podrobněji viz Filip Čapek, „Judské chrámy a svatyně v geopolitických souvislostech: Kritické zhodnocení“, in: Šárka Velhartická (ed.), 100 let české staroorientalistiky, předovýchodní archeologie a klínopisného bádání, Praha: Academia (v tisku).

47 Přehledově k tomu viz F. Čapek, Archeologie..., 128-137.

48 Takto již J. Maxwell Miller, ,,The Elisha Cycle and the Accounts of the Omride Wars“, Journal of Biblical Literature 85/4, 1966, 441-454, včetně přehledu staršího bádání, a nově srov. Manfred Oeming, ,,And the King of Aram Was at War with Israel': History and Theology in the Elisha Cycle 2 Kings 2-13“, in: Omer Sergi - Manfred Oeming - Izaak J. de Hulster (eds.), In Search of Aram and Israel: Politics, Culture and the Question of Identity, (ORA 20), Tübingen: Mohr Siebeck 2016, 401-412.

49 Zda bylo území Moábu obsazeno již za Omrího (886-875 př. n. 1.), se lze jen dohadovat. Sdělení ze 4. až 5. řádku stély, že Omrí, král Izraele, Moáb utlačoval, může odkazovat k dynastii Omríovců jako takové, tj. zvláště k Achabovi. 
dostává do defenzivy a postupně jsou zničena města, která Izrael na moábském území vybudoval a kolonizoval. ${ }^{50}$ Méša si na komemorativním nápisu připisuje zničení měst Atarót, ${ }^{51}$ odkud odnáší „,Davidův oltář‘52 (srov. ř. 12), a Nebó, které vyvraždí a zabité zasvěcuje bohům Aštaře a Kemóšovi (ř. 16-17), a navíc odtamtud bere nádoby jahvistického božstva (ř. 18). Zásadním sdělením je především zmínka o jahvistických nádobách, jež jsou dokladem vlivu náboženství Izraele také mimo jeho území. ${ }^{53}$ Daný textový nález je klíčový pro rekonstrukci šíření oficiálního jahvistického kultu mimo území Izraele do míst, která mocensky ovládal. O tom, že stejnému působení bylo ještě intenzivněji než Moáb vystaveno Judsko, spojené se svým severním sousedem pevnými dynastickými vazbami, nelze pochybovat.

\section{8. století př̀. n. l.: Reorganizace a centralizace}

Těsné sepětí politického a náboženského života Judska a Izraele lze vysledovat nejen na konci 9. stol., ale i v celé první polovině 8. stol. př. n. 1 . Jakkoli se představy o dynastických konstelacích vladařů Izraele ovlivňujících život v Judsku liší, ${ }^{54}$ jisté je, že Jeruzalém je až do roku 747 př. n. 1, kdy po čtyřiceti letech vládnutí v Samaří umírá Jarobeám II., subjektem podmaněným severu a že veškeré pokusy o větší samostatnost končí fiaskem. ${ }^{55} \mathrm{~V}$ předchozím období se severní království stává pravděpodobně již

50 Podrobně $\mathrm{k}$ omríovské architektuře a stavební činnosti mimo území Izraele viz I. Finkelstein, Zapomenuté království..., 109-145.

51 Podrobněji k Atarót včetně nejnovější bibliografie viz Khirbat Ataruz Project, $<$ http://www.ataruz.org >, [15. 10. 2019].

52 Toto čtení (moáb. aral $d w d h$ ) je sporné. Ke čtení „Dům Davidův“ na 31. řádku viz Jan Dušek, „Moáb“, in: Jan Dušek - Dalibor Antalík - Pavel Čech - Jana Mynářová (eds.), Jako pták v kleci: Epigrafické památky starověké Levanty, (Starověké písemnictví Levanty 5), Praha: Oikúmené 2013, 242-254. Proti tomu srov. Israel Finkelstein Nadav Na'aman - Thomas Römer, ,Restoring Line 31 in the Mesha Stele: The ,House of David“ or Biblical Balak?“, Tel Aviv 46/1, 2019, 3-11.

53 Podobně vyznívá sdělení z nápisu na podstavci oltáře nalezeného ve svatyni odkryté v Atarót v roce 2010. K tomu viz Chang-Ho Ji, „A Moabite Sanctuary at Khirbat Ataruz, Jordan: Stratigraphy, Findings, and Archaeological Implications “, Levant 50/2, 2018, 1-38.

54 Alternativa k tradičnímu pojetí: např. Filip Čapek, „Jehu and Joash in Ancient Near East Texts: Critical Reassessment“, Communio Viatorum 56/1, 2014, 23-34; Amitai Baruchi-Unna, „Jehuites, Ahabites, and Omrides: Blood Kinship and Bloodshed“, Journal for the Study of the Old Testament 42/1, 2018, 3-21. Srov. také Cat Quite, „Jehu's Slaughter of Judah's Royal Family at Beth-Eked (2 Kings 10:13-14): A Closer Look“, Zeitschrift für die alttestamentliche Wissenschaft 131/4, 2019, 537-548.

55 Viz konflikt judského Amasjáše (801-773 př. n. 1.) s izraelským Jóašem (803-787 př. n. 1.). Judský král je nejen poražen u Bét Šemeše, v důsledku čehož je vyloupen i Jeruzalém včetně chrámového pokladu, ale nakonec také zavražděn v Lakíši, kam uniká před povstáním v hlavním městě (srov. $2 K r$ 14,8-22). 
za pozdní vlády Jóachaze (818-802 př. n. 1., k tomu viz $2 K r$ 13) a dále pak Jóaše (802-787 př. n. 1.) a především Jarobeáma II. „velmocí“ v regionu a prodlouženou rukou Novoasyrské ř́̌še v jižní Levantě. ${ }^{56}$ Je to doba, kdy Izrael dosahuje největší územní expanze a získává převahu nad AramDamaškem v oblasti Zajordání a Galileje až po Tel Dan. ${ }^{57}$ Vazbu Judska na Izrael dokládá nalezený epigrafický materiál. ${ }^{58}$ Až na prahu druhé poloviny 8. stol. př. n. 1. dochází k osamostatnění Judska v důsledku nového vzestupu vlivu Novoasyrské říše za Tiglat-pilesara III. (745-727 př. n. 1.), který podniká několik tažení na západ a dostává pod tlak nejprve AramDamašek a dále Izrael vedený Nimšíovci. ${ }^{59}$ Vliv Samaři daleko na jihu dokládají nálezy textů a ikonografického materiálu polyjahvistické ${ }^{60}$ povahy z Kuntillet Adžrud, místa při arabské obchodní stezce Darb el-Ghazza v Negevu, obsahujících žehnající formule ,při Jahvem ze Samaří a jeho

56 To je zřetelné např́klad díky stéle z Tell al-Rimach. Na té je judský Jóaš označovaný jako král ze země Samaří (KUR Sa-me-ri-na-a-a) a pak také jako vazal, jenž musí od roku 796 př. n. 1. platit Adad-nerarímu tribut.

57 Doklady tohoto jsou strata Tel Dan II, Kinneret II, Chásor VI/IVA, Jokneám XIII a Jibleám X. Viz Eran Arie, ,Reconsidering the Iron Age II Strata at Tel Dan: Archaeological and Historical Implications“, Tel Aviv 35/1, 2008, 6-64. Srov. Omer Sergi - Assaf Kleiman, „The Kingdom of Geshur and the Expansion of AramDamascus into the Northern Jordan Valley: Archaeological and Historical Perspectives“", Bulletin of the American Schools of Oriental Research 379, 2018, 1-18.

58 Z doby vlády Azarjáše (787-736 př. n. 1.), uváděného starozákonními texty také jako Uzijáš (tak úvody knih Izajáš, Ozeáš, Ámos a pak $1 K r$ 15,13.30.32.34 a až na jednu výjimku důsledně v $2 \mathrm{~Pa}$ ), jsou pravděpodobně nalezené pečeti a pečetítka se jmény králových služebníků Šebanjáva a Abíjáva, pocházejících ze severu. Podoba jmen je typicky izraelská, protože obsahují teoforní prvek -jáv, a nikoli judská (zde jsou typickými prvky jehó-, -jáhú a -jáh). Přestože jde o epigrafický materiál z nezajištěného zdroje (nyní uložen v Louvre a v Národní knihovně v Paříži), souvislost s králem se zdá být pravděpodobná. K tomu Nahman Avigad - Benjamin Sass, Corpus of West Semitic Stamp Seals, Jerusalem: The Israel Academy of Sciences and Humanities 1997; Lawrence J. Mykytiuk, Identifying Biblical Persons in Northwest Semitic Inscriptions of 1200-539 B.C.E., (SBL Academia Biblica 12), Atlanta, GA: SBL Press 2004, a F. Čapek, Archeologie..., 154-155.

59 Jde o vojenské kampaně v letech 742, 741, 740, 738, 734, 732 a 731. K přehledu viz Jeffrey Kah-Jin Kuan, Neo-Assyrian Historial Inscriptions and Syria-Palestine: Israelite/Judean-Tyrian-Damascene Political and Commercial Relations in the NinthEighth Century BCE, Eugene, OR: Wimp and Stock 2016.

60 „Polyjahvismus“ je označením náboženského jevu, kdy má božstvo Jahve své místní manifestace vyjádřené vazbou ,Jahve z té a té lokality“. 
Ašeře“ a „při Jahvem z Témanu“, 61 a nástěnných kreseb zobrazujících pravděpodobně Jarobeáma II. ${ }^{62}$

Při čtení biblických textů, dalších ze starověkých literárních dokladů, byt sepisovaných z pozdější perspektivy, je zřetelné, že v líčení konce 9. stol. př. n. 1. a první poloviny 8. stol. př. n. 1. je nápadný důraz kladen na oddělení Judska od severu prostřednictvím svébytných dynastických souvislostí (důraz na davidovskou linii, uvádění matky nastupujícího panovníka a jejího judského původu) a na náboženské vymezení. ${ }^{63} \mathrm{~V}$ jeho rámci je Judsko líčeno jako místo řádně praktikovaného jahvistického kultu, případně jsou připojeny sebezpytující výhrady, pokud tomu tak není, a Izrael naopak jako země, jež tento kult neustále porušuje a slouží Baalovi a dalším bohům. ${ }^{64}$ Podobně nápadná je na druhou stranu i těsná spjatost s politickým děním v Izraeli, kterou nelze zcela zamlčet. ${ }^{65}$

Započatý proces osamostatňování Judska lze sledovat ve starozákonních prorockých textech, které se vztahují k době vládnutí judských a izraelských králů první a počátku druhé poloviny 8. stol. př. n. 1. Nejstarší z písemných proroků Ozeáš tvrdí, že Izrael je „umíněný jako umíněná kráva“ $(O z, 4,16)$, čímž se stigmatizuje sever jako odstrašující př́íklad pro jih. Kritika Samaří proniká neúprosně všemi sférami života. Pranýřována je nejahvistická kultická praxe, označovaná jako zběhnutí, porušení sňatku a smilstvo. Ani kněží, ani představitelé moci nejsou hodni svého poslání, protože svádějí lid na scestí. To vše je vysvětlováno právě na pozadí jednání Izraele, které je křiklavým svědectvím o celkové „,baalizaci“ severního státního útvaru a opuštění jahvistického kultu. Další z prorockých tradic (reprezentuje ji Ámos), situovaná do doby vládnutí judského krále Uzijáše (Azarjáše) a právě nastupujícího izraelského Jarobeáma II., je soustředěna

61 Ze'ev Meshel, Kuntillet Ajrud (Horvat Teman): An Iron Age II Religious Site on the Judah-Sinai Border, Jerusalem: Israel Exploration Society 2012. V českém prostředí tematiku dobře představil Dalibor Antalík, ,Jahve a jeho paredros v náboženství předexilního Izraele“, Religio: Revue pro religionistiku 4/2, 1996, 127-138.

62 Např. Tallay Ornan, ,Sketches and Final Works of Art: The Drawings and Wall Paintings of Kuntillet "Ajrud Revisited“, Tel Aviv 43/1, 2016, 3-26. Srov. Z. Meshel, Kuntillet Ajrud..., který co do datování počítá přibližně s rokem 800 př. n. 1., a tím ještě s vládou Jóaše.

63 K tomuto viz F. Čapek, Archeologie..., 142.

64 Ibid., 148.

65 Jedním z předpokládaných důvodů je i to, že po pádu Samaří v roce 722 př. n. 1. odešla řada Izraelcủ i se svými literárními tradicemi na jih, a proto judští písaři podle řady badatelů museli tyto tradice integrovat do metanarativu jednoho Izraele (k tomu viz dále). Tato představa, reprezentovaná už zmíněným kompromisním modelem, má svá úskalí, a to (a) časové, nebot propojenost obou království existovala již dřive, a (b) obsahové, protože sever je kritizován natolik silně, že si lze sotva představit, že by přinejmenším první dvě či tři generace Izraelců tvrdou kritiku vlastní původní „vlasti““ mohli přijmout za svou. 
na nesmlouvavou kritiku severu, který přestává být Izraelem, protože jeho novou transformovanou podobou je Judsko s centrem pravého monoteistického kultu v jeruzalémském chrámě.

Vztah možná ještě existujícího Izraele na začátku druhé poloviny 8. stol. př. n. 1. a Judska pojednává nejobsáhlejší z prorockých knih Izajáš (zejména $\mathrm{v}$ nejstarších částech $I z, 6,1-8,18)$. Tématem je existence severu a jihu jako dvou souvisejících domů. První dům, Izrael (dále specifikovaný jako Efraim, Samaří a Jákob), je pro druhý, Judsko (Jeruzalém, Sijón), varováním a př́kladem, jak nejednat. Dějinným kontextem jsou syrsko-efraimské války (736-732 př. n. 1.) a ohrožení Judska aramejským Resínem a izraelským Pekachem (Iz 7,1). Izajáš ve svém pojednání píše o dvou izraelských domech, které jsou svými dějinami i svými osudy spojeny na základě diferenciované identity. ${ }^{66}$ Příklady ze tř́ prorockých tradic jsou dalším dokladem těsného sepětí Judska a Izraele, které lze podobně identifikovat $\mathrm{v}$ příbězích o praotcích, kmenech, předcích anebo na pozadí dynasticky spř́izněných panovníků, jejichž původ je třeba hledat na severu. ${ }^{67}$

Podstatným prvkem souvisejícím s budoucím důrazem na kult jednoho boha je centralizace a reorganizace kultu. Tento trend souvisí s hospodářským a politickým vývojem Izraele a Judska i uspořádáním společnosti, která je stále více soustředěna kolem městských center a tamních chrámů. Finkelstein má za to, že se Judsko, ,inspirovalo změnami v kultických zvyklostech v Izraeli“68 možná desetiletí před pádem Samaří, tj. v první polovině 8. stol. př. n. 1., anebo že důraz na centralizaci přišel až s proudem uprchlíků po roce 722 př. n. l. Součástí centralizace, tvrdí dále tento izraelský archeolog, je to, že v „Izraeli, stejně jako v Judsku, reorganizace kultu pravděpodobně souvisela též s počátkem kompilace svatých písem v centrálních, králem ovládaných svatyních, jako např. ve svatyni v Bét Elu“69 Jako pravděpodobnější se zdá být první z možností, protože intenzivní interakce mezi Izraelem a Judskem se započaly již dříve v 9. stol. př. n. 1 . a pokračovaly také $\mathrm{v}$ první polovině 8 . stol. př. n. 1., na jehož konci se Jeruzalém od svého, tou dobou již oslabeného, severního souseda plně osamostatnil a nakonec převzal jeho politickou, kulturní i náboženskou identitu formou výrazného odlišení a nového sebevymezení. Rozvoj jihu

66 Takto zvláště Kristin Weingart, Stämmevolk - Staatsvolk - Gottesvolk? Studien zur Verwendung des Israel-Namens im Alten Testament, (FAT II 68), Tübingen: Mohr Siebeck 2014; ead., שני בתי ישראל (Isa 8:14): Concepts of Israel in the Monarchic Period“, in: Manfred Oeming - Petr Sláma (eds.), A King Like All the Nations? Kingdoms of Israel and Judah in the Bible and History, (BVB 28), Münster: Lit Verlag 2015, 21-32, a ead., ,Eine zweite Chance für Israel? Gericht und Hoffnung in Hos 3,15“, Biblica 97/3, 2016, 342-359.

67 K tomuto podrobněji F. Čapek, Archeologie..., 155-158.

68 I. Finkelstein, Zapomenuté království..., 170.

69 Ibid. 
tedy není nutně až důsledkem masového exodu Izraelců ze severu, o kterém chybí jasnější archeologický dokladový materiál, nýbrž nastal již dříve. ${ }^{70}$

Ukázkovým příkladem, jak náboženská transformace severních tradic a převzetí jahvismu jako hlavního náboženství probíhaly, je kritika Bét Elu (a tím potažmo celého Izraele). Toto místo je cíleně stigmatizováno, aby původní důležitost lokality upadla co nejvíce v zapomnění. Dějiny severu jsou ,přepisovány“ v $1 K r$ 12-13, textu, jenž prošel několika redakcemi. ${ }^{71}$ V tomto delším vyprávění je zřetelný zápas o dědictví pravého „Izraele“, na jehož konci stojí formou proroctví potvrzený vzorový král Jóšijáš (639609 př. n. 1.) a jím spravované Judsko (viz dále takto v $2 K r$ 23,15-20), který Bét El „očištuje“, protože právě zde Jarobeám I. zavedl kult býčka (podobně i na severu v Danu). ${ }^{72}$

Pomyslné reálie, které lze v textu a za textem identifikovat, se vztahují nejprve k fiktivní roztržce na konci 10. stol. př. n. 1. za „prvního“ Jarobeáma a pak $\mathrm{k}$ jeho historicky doložitelnému jmenovci působícímu o dvě století později. To on je skutečnou dějinnou postavou a musí být zavržen, aby byl „odmítnut tamní centralizovaný státní kult, který podporoval vnitřní politickou stabilitu a legitimitu vladaře“"73 Býček, jedna z ikonograficky doložených reprezentací jahvistického božstva, ${ }^{74}$ který je v Bét Elu podle judské vícestupňově pojaté delegitimizační zprávy uctíván, „svádí lid k hříchu“ (1Kr 12,30) a tamní kněží jsou ustavení ze „spodiny lidu“ $(1 K r 12,31)$. Uvedenou modloslužbu býčka je třeba považovat za literární konstrukci, jejímž cílem je zviditelnit Jarobeámův hřích a zesměšnit ho jako zakladatele první dynastie v Izraeli, ${ }^{75}$ tedy diskreditovat sever od samotných počátkủ. Shrnuto, historickou postavou skrytou za příběhem je Jarobeám II., který se transformoval do stejnojmenné historicky nedoložené postavy konce 10. stol. př. n. 1., jež je ,zodpovědná“ za

70 Ernst A. Knauf - Philippe Guillaume, A History of Biblical Israel: The Fate of Tribes and Kingdoms from Merenptah to Bar Kochba, Sheffield: Equinox 2016, 110.

71 Lydie Kucová, Common Source Theory and Composition of the Story of the Divided Monarchy in Kings with Special Emphasis on the Account of Josiah's Reform [rukopis dizertační práce], Edinburgh: University of Edinburgh 2005.

72 Srov. F. Čapek, Archeologie..., 161.

73 Klaus Koenen, Bethel: Geschichte, Kult und Theologie, (OBO 192), Freiburg: Universitätsverlag - Göttingen: Vandenhoeck und Ruprecht 2003, 132.

74 Srov. Othmar Keel - Christoph Uehlinger, Göttinen, Götter und Gottessymbole: Neue Erkenntnisse zur Religionsgeschichte Kanaans und Israels aufgrund bislang unerschlossener ikonographischer Quellen, (QD 134), Freiburg - Basel - Wien: Herder ${ }^{4}$ 1999, 199-281.

75 Juha Pakkala, ,Jeroboam without Bulls“, Zeitschrift für alttestamentliche Wissenschaft 120/4, 2008, 501-525; Thomas Römer, „How Jeroboam II Became Jeroboam I“, Hebrew Bible and Ancient Israel 6/3, 2017, 372-382; Ernst A. Knauf, „Jeroboam ben Nimshi: The Biblical Evidence“, Hebrew Bible and Ancient Israel 6/3, 2017, 290-307. 
rozpad ideálně-typického Sjednoceného království. Konfrontační tón textu, který má i své další následné dějiny zpracování, ${ }^{76}$ je nezbytné interpretovat jako výraz touhy po oddělení, odlišení a stanovení hranic nového státního útvaru, již plně samostatného Judska. ${ }^{77}$

Prvním panovníkem samostatného Judska se stává Achaz (741-725 př. n. 1.), kterému je až v poslední době v bádání věnována odpovídající pozornost. Byl to právě on, a nikoli až Chizkijáš (725-697 př. n. 1.), kdo díky pragmatické politice spolupráce s Novoasyrskou říší zemi stabilizoval díky výrazné ekonomické a náboženské centralizaci, jejíž součástí je i přebudování části areálu jeruzalémského chrámu včetně oltáře. Ekonomická centralizace je doložitelná za pomoci analýzy otisků pečetí s hebrejským nápisem lamelech (,„patřící králi“) na zásobnicích (nádoby o objemu 40-50 litrů určené pro výběr a transport komodit odváděných jako daň panovníkovi). Nově zpracovaná typologie těchto pečetí potvrzuje, že ekonomická centralizace započala dř́ive ${ }^{78}$ než se ve starším bádání usuzovalo, a že přímo souvisí se začleněním Judského království do asyrského systému vazalských států nejpozději v roce 734 př. n. 1., tedy za Achaze. ${ }^{79}$

76 K tomu srov. např. $2 K r$ 17,24-33, která se vztahuje k závěru 8. stol. př. n. 1. a všímá si toho, jakým způsobem praktikuje Izrael náboženský život. Tiglat-pilesar III. podle biblické zprávy posílá z exilu zpět do Izraele, do Bét Elu, kněze, kteří tam učí lid ,̌rád Boha té země“ (v. 27). Vyučovanými jsou rovněž Samařané (hebr. Šómróním; hapax). Lze se domnívat, že text odráží napětí mezi Judskem a Samařím v době perské. K tomu viz Gary N. Knoppers, „Revisiting the Samarian Question in the Persian Period“, in: Oded Lipschits - Manfred Oeming (eds.), Judah and the Judeans in the Persian Period, Winona Lake, IN: Eisenbrauns 2006, 265-289.

77 Viz F. Čapek, Archeologie..., 162.

78 Nádoby byly analyzovány petrograficky i morfologicky s pomocí 3D skenování, aby se zjistil původ materiálu, z něhož byly vyrobeny, aby byly identifikovány specifické hrnčířské tradice a rozpoznány trasy oběhu těchto nádob. Datování uživání pečení bylo rozšiřeno na dobu před rokem 701 př. n. 1. díky revizi stratigrafie lokality Lakíš. K tomu viz Yuval Goren, „Excursus: Petrographic Analysis of $l m l k$ and Official Sealed Jars Handles from the Renewed Excavations", in: Shlomo Bunimovitz - Zvi Lederman (eds.), Tel Beth-Shemesh: A Border Community in Judah: Renewed Excavations 19902000: The Iron Age II, Winona Lake, IN: Eisenbrauns 2016, 502-504; Oded Lipschits - Omer Sergi - Ido Koch, „Royal Judahite Jar Handles: Reconsidering the Chronology of the Imlk Stamp Impressions", Tel Aviv 37, 2010, 3-32; Omer Sergi - Avshalom Karasik - Yuval Gadot - Oded Lipschits, „,The Royal Judahite Storage Jar: A Computer-Generated Typology and Its Archaeological and Historical Impliciation", Tel Aviv 39, 2012, 64-92; Oded Lipschits, ,Judah under Assyrian Rule and the Early Phase of Stamping Jar Handles“, in: Jacob L. Wright - Zev I. Farber (eds.), Archaeology and History of Eighth-Century Judah, Atlanta, GA: SBL Press 2018, 337-355.

79 Achaz je prvním panovníkem Judska doloženým mimobiblickými texty. Konkrétně se jedná o záznam vazalů Tiglat-pilesara III., jenž se váže k roku 734 př. n. 1., kde se Achaz, uváděný v delší formě jako Jóachaz Judský ( ${ }^{m} I a-u$ - $\left.h a-z i{ }^{k u r} I a-u-d a-a\right)$, spolu se správci Aškelónu, Amónu, Moábu a Edómu podrobuje Asýrii. 
Stanovit jasné dějinné kontury náboženské centralizace je složitější, a to i proto, že je na základě biblických textů, jež zásadním způsobem ovlivnily generace archeologů, biblistů a historiků, spojována výhradně s Chizkijášem. Zrušení a konzervaci svatyň v Aradu, Beer Šebě, Lakíši a možná i Tel Moce lze nicméně připisovat již Achazovi. Totéž platí pro další důležité podniky, jakými byla centralizace výběru daní (viz lamelech otisky), výstavba pevností, opevnění, vodních tunelů a kanálů, které nejsou až důsledkem Chizkijášova vzdoru vůči Asýrii po roce 706 př̀. n. 1., ale logickou součástí spolupráce, byt vnucené, s politickým hegemonem. Perspektiva nabízená biblickými texty je založená na retrospektivních nacionalistických zájmech, které jsou promítány do všech sfér, především pak do oblasti kultu. ${ }^{80}$ Dokladem o ambivalentním vztahu biblické historiografie k Achazovi je obsáhlý text $2 K r 16$, který je na jedné straně vůči tomuto králi nesmlouvavý, na straně druhé je zvláštně shovívavý k jeho úpravám oltáře. Důvodem může být, že oltář byl přebudován podle plánů jahvistického oltáře v Damašku, který byl inspirován praxí Izraele. ${ }^{81}$

I přes uvedený důraz na centralizaci náboženství je z povahy nalezeného dokladového materiálu i v 8. stol. př. n. 1. zřetelné, že náboženská praxe je velmi rozmanitá, synkretistická, odlišná v centrech a mimo ně. Dominantní jahvistický kult má své „lokální manifestace“"82 s řadou synkretizujících prvků. Samostatnou kapitolu představují JPF, kterým bude dále věnována pozornost. I proto nelze metodologicky směšovat centralizaci s monoteismem, který se nestává plně doložitelnou skutečností ani v následujícím století.

\section{7. století př. n. l.: Co se tehdy vlastně stalo?}

Do posledního dlouhého století svých dějin nevstupuje Judské království dobře. Děje se tak kvůli politickému experimentu Chizkijáše (728-687 př. n. 1.), který se vzbouřil proti asyrské nadvládě. Výsledkem je katastrofální destrukce řady míst novoasyrskými vojsky v roce 701 př. n. 1. a ztráta některých důležitých území. Změnu přináší politicky uvážlivé jednání Menašeho (687-642 př. n. 1.), který jako další správce judského satelitního

80 K tomu podrobněji F. Čapek, Archeologie..., 179-198.

81 Nili Wazana, „Ahaz and the Altar from Damascus (2Kings 16:10-16): Literary, Theological, and Historical-Political Considerations“, in: Omer Sergi - Manfred Oeming - Izaak J. de Hulster (eds.), In Search of Aram and Israel: Politics, Culture and the Question of Identity, (ORA 20), Tübingen: Mohr Siebeck 2016, 379-400. Srov. ale Mark W. Hamilton, A Kingdom for a Stage: Political and Theological Reflection in the Hebrew Bible, (FAT 116), Tübingen: Mohr Siebeck 2018.

82 Zev I. Farber, „Religion in Eighth-Century Judah: An Overview“, in: Jacob L. Wright - Zev I. Farber (eds.), Archaeology and History of Eighth-Century Judah, Atlanta, GA: SBL Press 2018, 431-454: 432. 
státu pochopil, že klíčem $\mathrm{k}$ hospodářské prosperitě a relativní politické nezávislosti je loajalita vůči Asýrii. ${ }^{83}$ Epizodické období vlády jeho nástupníka Amóna (641-640 př. n. 1.), který je zavražděn patrně někým z nacionalistických kruhů, střídá dlouhá správa země za Jóšijáše (639-609 př. n. 1), spojovaného tradičně s náboženskou reformou a obnovou monoteismu, který v předchozích dekádách podle biblických textů upadl v zapomnění.

Z hlediska biblické historiografie podávané knihami Královskými má 7. stol. př. n. 1. jediného nábožensky příkladného panovníka, Jóšijáše. Ten je dáván za vzor poslušnosti výhradnímu jahvistickému kultu. Zbývající vladaři slouží jako negativní pozadí, na kterém Jóšijáš vystupuje jako zachránce Judska a pravé víry. Menaše má v tomto líčení zcela jinou roli. Ačkoli je nejdéle vládnoucím králem a původcem stability, je přirovnáván k prototypům špatnosti Jarobeámovi a Achabovi (oba ze severu!), protože buduje Baalovi oltáře v Hospodinově domě, kam umistuje i modlu Ašery (viz $2 K r$ 21,1-18). Menaše je tím, v kom se kumulují všechny hříchy Izraele od doby, co „vyšli ... otcové [tj. Izrael] z Egypta, až dodnes“ ( $2 K r 21,15)$. Výsledkem takto pojatého líčení je programový historický výhled, že to bude právě Menaše, kdo se stane zodpovědným také za pád Judského království. ${ }^{84}$ Důvodem takto retrospektivně pojatého vidění je podle všeho protiasyrský osten (ten je podobný i u dvojice Achaz - Chizkijáš) tradovaný nacionálními a náboženskými kruhy, z nichž vzešlo tzv. deuteronomistické hnutí, prosazující výlučné postavení jahvistického kultu. ${ }^{85}$

Starší bádání považovalo biblické líčení náboženského dění za víceméně věrný historický popis, a proto přišlo s tvrzením o asyrské krizi izraelského náboženství první poloviny 7. stol. př. n. 1., která nastala s Menašem poplatným Asýrii a jež byla odstraněna radikální reformou kultu za Jóšijáše. ${ }^{86}$ Asyrský kult byl podle této představy mocensky importován do

83 Srov. F. Čapek, Archeologie..., 144.

84 Srov. líčení knih Paralipomenon, které s postavou Menašeho pracuje zcela jinak. K tomu viz David Cielontko, „Two Faces of Manasseh: The Reception of Manasseh in the Literature of Early Judaism“, in: Filip Čapek - Oded Lipschits (eds.), The Last Century in the History of the Kingdom of Judah: The $7^{\text {th }}$ Century BCE in Archaeological, Historical and Biblical Perspective, Atlanta, GA: SBL Press 2019, 239-260.

85 Albert de Pury - Thomas Römer - Jean-Daniel Machi (eds.), Israel Constructs Its History: Deuteronomistic Historiography in Recent Research, (JSOTSup 306), Sheffield: Sheffield Academic Press 2000; Jan Rückl - Martin Prudký, „Literární a teologický charakter Předních proroků - tzv. deuteronomistické dějepravné dílo“, in: Martin Prudký - Jan Heller et al., Obtǐžné oddíly Předních proroků, Kostelní Vydří: Karmelitánské nakladatelství 2013, 367-381. Srov. také Otto Eckart, Das Deuteronomium: Politische Theologie und Rechtsreform in Juda und Assyrien, (BZAW 284), Berlin: de Gruyter 1999.

$86 \mathrm{Za}$ všechny Herbert Donner, Geschichte des Volkes Israel und seiner Nachbarn in Grundzüge I-II, Göttingen: Vandenhoeck und Ruprecht 1987 ( $\left.{ }^{2} 1995\right)$. 
Judska, prostoru dominantního jahvistického kultu, tak, že se do popředí dostává uctívání Baala, Ašery a nebeských zástupů jako transformovaných podob asyrských božstev. Novější bádání tento obraz upravuje. V oblasti ikonografie skutečně v Judsku dochází k postupnému pronikání asyrských a aramejských vlivů, ale tento trend není vymáhán násilně, nýbrž je důsledkem dlouhotrvajícího kulturního vlivu, kterému je Judsko, stejně jako další vazalové Asýrie, vystaveno. ${ }^{87}$ Proto jsou „místní božstva Jahve a Ašera přesazeni do soudobých kategoriî“ “ 88 jsou typologicky, svým jednáním, svými atributy, připodobňováni Aššurovi a Ištaře, i když na tato jména $\mathrm{v}$ biblických textech nenarazíme. ${ }^{89}$ Nic takového jako program asyrizace kultu se v Judsku v 7. stol. př. n. 1. neodehrálo. ${ }^{90}$ Archeologický dokladový materiál zásadní rozdíly v náboženském životě Judska mezi Menašem a Jóšijášem a následně Jojakímem nepotvrzuje.

Fenoménem sui generis, již dříve zmíněným, jsou JPF nalezené v řádu tisíců zvláště v judských domácnostech, ale také v místech interpretovaných jako favissy přiléhající ke svatyni. ${ }^{91}$ I zde se oproti dřivějšímu bádání interpretace posunula od jednoznačnějších a vyhraněnějších poloh (JPF jako reprezentace Ašery versus tatáž figurka jako předmět bez náboženských konotací, popř. hračka) $\mathrm{k}$ jemnějším rozlišením. To je zřetelné z nedávného výkladu Farbera tvrdícího, že „nevíme, jestli Judejci považovali figurku za obecné ,nižší nebo ,zprostředkující‘ božstvo, anebo za určitou vyšší bohyni“ a že je na druhou stranu ,,jasné, že se nejednalo pouze o dekorativní znázornění ženy“, protože ,,[JPF] byly určeny k rituálním účelům, což posiluje domněnku, že bohyně měly v judském náboženství svoji roli ..."92 Erin Darby, v současnosti největší znalkyně JPF problematiky, má za to, že figurky sloužily zejména ve městech jako polobožské entity a apotropaické patronky uzdravení. ${ }^{93}$ Ještě zdrženlivější je Josef Briffa,

87 Ido Koch, „Pictorial Novelties in Context: Assyrian Iconography in Judah“, Filip Čapek - Oded Lipschits (eds.), The Last Century in the History of the Kingdom of Judah: The $7^{\text {th }}$ Century BCE in Archaeological, Historical and Biblical Perspective, Atlanta, GA: SBL Press 2019, 153-166.

88 A. Berlejung, Náboženské dějiny..., 185.

89 Srov. David T. Sugimoto (ed.), Transformation of a Goddess: Ishtar - Astarte Aphrodite, (OBO 263), Fribourg: Academic Press - Göttingen: Vandenhoeck und Ruprecht 2014.

90 Podrobněji k náboženským poměrům a asyrizaci za Menašeho viz F. Čapek, Archeologie..., 193-198.

91 Tak např. Jeskyně I v Jeruzalémě, nalezená v roce 1967 Kathleen Kenyon, nebo favissa v sektoru E v Davidově městě, odkrytá v 80. letech 20. století.

92 Z. I. Farber, „Religion in Eighth-Century Judah...“, 436.

93 Erin Darby, „Judean Pillar Figurines (JPFs)“, in: Jacob L. Wright - Zev I. Farber (eds.), Archaeology and History of Eighth-Century Judah, Atlanta, GA: SBL Press 2018, 401414, a zejm. ead., Interpreting Judean Pillar Figurines: Gender and Empire in Apotropaic Ritual, (FAT 2, Reihe 69), Tübingen: Mohr Siebeck 2014. 
který nezpochybňuje důležitost JPF, ale zdráhá se potvrdit, že měly výhradně náboženskou (v domácím kultu), či profánní funkci ${ }^{94}$ Nehledě na přesnou funkci JPF je zřetelná jejich kontinuita, podobně jako $\mathrm{v}$ př́ípadě dalších náboženských artefaktů, také v celé druhé polovině 7. stol. př. n. 1 . Existence reformy není archeologicky doložitelná, oproti lépe zdokumentované centralizaci za Achaze (popř. Chizkijáše), ani v hmotné kultuře související s oficiálním kultem. To potvrdil například nedávný revizní průzkum v Tel Aradu, na základě něhož došlo k upravení stratigrafie v neprospěch teze, že stratum VII dosvědčuje odstranění oltáře za Jóšijáše. ${ }^{95}$

Otázkou tedy je, co tato zjištění znamenají pro výklad tzv. Jóšijášovy reformy datované biblickými texty k roku 622 př. n. 1. Jako nejpravděpodobnější se zdá, že určité tendence k prosazení výhradního monoteismu byly v Jeruzalémě za vlády Jóšijáše přítomny v kruzích kolem chrámu a politických elit, ale šířeji se neprosadily. ${ }^{96}$ Zásadní je datování biblických textů, které mohou být ještě předexilní, tedy sepsané do roku 586 př. n. 1., anebo až exilní (586-539 př. n. 1.) či poexilní (po roce 539 př. n. 1.). V bádání nepanuje shoda, zda jsou z doby ještě existující monarchie alespoň jejich nejstarší části, anebo zda i ty jsou až zpětným pohledem na království po jeho zániku. Existence JPF, figurek koníků (s jezdcem i samostatně) a dalších artefaktů náboženské povahy ještě nevylučuje reformu, která mohla být nacionální reakcí na oslabování asyrského vlivu v regionu ${ }^{97}$ a jež bezesporu měla, podobně jako o století dřive za Chizkijáše, bezpro-

94 Josef Mario Briffa, „,Through a Glass Darkly: Figurines as a Window on the Past“, in: Filip Čapek - Oded Lipschits (eds.), The Last Century in the History of the Kingdom of Judah: The $7^{\text {th }}$ Century BCE in Archaeological, Historical and Biblical Perspective, Atlanta, GA: SBL Press 2019, 181-199. Srov. id., The Figural World of the Southern Levant during the Late Iron Age [rukopis dizertační práce], London: Institute of Archaeology, University of London 2017.

95 Ze'ev Herzog, ,The Date of the Temple at Arad: Reassessment of the Stratigraphy and the Implications for the History of Religion in Judah“, in: Amihai Mazar (ed.), Studies in the Archaeology of the Iron Age in Israel and Jordan, Sheffield: Sheffield Academic Press 2001, 151-178; id., „The Fortress Mound at Tel Arad: An Interim Report“, Tel Aviv 29/1, 2002, 3-109, a id., „Perspectives on Southern Israel's Cult Centralization: Arad and Beer-sheba“, in: Reinhard G. Kratz - Hermann Spieckermann (eds.), One God, One Cult, One Nation: Archaeological and Biblical Perspectives, (BZAW 405), Berlin - New York: de Gruyter 2010, 169-199.

96 Ke kritičtějšímu pohledu odmítajícímu existenci reformy jako takové viz Ernst A. Knauf, „The Glorious Days of Manasseh“, in: Lester L. Grabbe (ed.), Good Kings and Bad Kings, New York - London: T and T Clark 2005, 164-188: zejm. 166-168, nebo Juha Pakkala, „Why the Cult Reforms in Judah Probably Did Not Happen“, in: Reinhard G. Kratz - Hermann Spieckermann (eds.), One God, One Cult, One Nation: Archaeological and Biblical Perspectives, (BZAW 405), Berlin - New York: de Gruyter 2010, 201-235.

97 Výstižně např. Othmar Keel, Die Geschichte Jerusalems und die Entstehung des Monotheismus, Göttingen: Vandenhoeck und Ruprecht 2007, 546: „Pád velkých impérií, takových, jakým byla Novoasyrská říše, zpravidla doprovází znovuobnovený zájem 
stř̌ední fatální následky v podobě násilné smrti krále „reformátora““98 $\mathrm{Z}$ hlediska sledovaného tématu nejsme ani tak svědky náhlých a dalekosáhlých změn, ale spíše kontinuity a koexistence náboženských tradic, z nichž některé vykazují monoteizující tendence, které mají svůj prvopočátek v centralizaci kultu $\mathrm{v}$ předchozím století. Náboženství v Judsku na konci 7. stol. př. n. 1., ale i ještě v začínajícím 6. stol. př. n. 1. je spletitým komplexem promíšené náboženské praxe, která je rozrůzněna sociálně, zeměpisně a souvisí s intenzivní intelektuální konceptualizací vlastní identity. ${ }^{99}$

\section{6. století př. n. l.: Zde to všechno ,začalo“}

Neúplné dvě dekády samostatného Judského království v 6. stol. př. n. 1 . nepřinášejí zvrat v podobě hmotné kultury kultické povahy ( $\mathrm{k}$ té viz dříve). Pozornost si zaslouží znovu texty týkající se Jóšijášovy reformy a $\mathrm{v}$ nich obsažené reálie (zvl. $2 K r$ 23). Ve výčtu odstraněných objektů, které kolidují s představou anikonického monoteismu, patří koně stojící před chrámem, konkrétně před komnatou strážce Nátan-melecha. Někteří ojedinělý výraz komnata, hebr. farwárím (Septuaginta pouze transliteruje), spojují s chetitským božstvem Pirwa, které je znázorňováno jako kůň. Tato spojitost je sporná a vychází spíše z tematického kontextu a intuitivní etymologizace výrazně geograficky a časově vzdálené náboženské skutečnosti. ${ }^{100}$ Jisté naopak je, že tentýž text líčí zničení slunečních vozů (hebr. rechovót hašemeš), které jsou nicméně ikonograficky doloženy až z řeckého znázornění Helia na kvadrize pocházející z pozdního 6. stol. př. n. $1{ }^{101} \mathrm{Na}$

o místní uspořádání a hodnoty a ruku v ruce s tím i požadavek přehnaných místních nároků.“

98 Ironií dějin je, že Jóšijáš, který je hodnocen lépe než Šalomoun (viz $2 K r$ 23,13.25), končí násilnou smrtí, když je zabit v Megiddu pravděpodobně na popud egyptského faraóna Néka II. (610-595 př. n. 1.). Srov. Zipora Talshir, „The Three Deaths and the Strata of Biblical Historiography“, Vetus Testamentum 46/2, 1996, 213-236; Joseph Blenkinsopp, „Remembering Josiah,“ in: Diana V. Edelman - Ehud Ben Zvi (eds.), Remembering Biblical Figures in the Late Persian and Early Hellenistic Period: Social Memory and Imagination, Oxford: Oxford University Press 2013, 236-256.

99 Podrobněji viz Filip Čapek, „King Josiah Between Eclipse and Rebirth: Judah of the $7^{\text {th }}$ Century BCE in History and Literature“, in: Filip Čapek - Oded Lipschits (eds.), The Last Century in the History of the Kingdom of Judah: The $7^{\text {th }}$ Century BCE in Archaeological, Historical and Biblical Perspective, Atlanta, GA: SBL Press 2019, 45-59.

100 Srov. Franca P. Daddi, „Pirwa, Peruwa“, in: Dietz O. Edzard - Michael P. Streck (eds.), Reallexikon der Assyriologie und Vorderasiatischen Archäologie X, Berlin New York: Walter de Gruyter 2005, 573-575, nebo Michele Cammarosano, Hittite Local Cults, (Writings from the Ancient World 40), Atlanta, GA: SBL Press 2018, 72-76.

101 O. Keel, Die Geschichte Jerusalems..., 537. 
nesmlouvavé kritice kontaminace kultu za posledních judských králů nemění nic ani teze Keela a Uehlingera, kteří koně nepovažují za božstvo, nýbrž za předmět zprostředkovávající přítomnost jahvistického božstva v solárním kontextu a jako př́mluvce $\mathrm{v}$ rámci rodinné zbožnosti (něm. Familiefrömigkeit). ${ }^{102}$

Mezi domácí zbožností a oficiálním centralizovaným projahvistickým kultem v Judsku existovala nejen symbióza, ale i napětí, které bylo tématem reformy, byt byl její dopad spíše omezený. Na základě výše uvedených postřehů je zřejmé, že text líčící reformu pochází jako celek až z doby po pádu Jeruzaléma a není ani tak popisem kultického inventáře chrámu a přilehlých prostor, ale programovým prohlášením o tom, co by nemělo patřit k řádnému monoteistickému kultu, tak jak jej dále rozepisují nařízení obsažená v Pentateuchu, vzniklá rovněž až v exilně-poexilní době. ${ }^{103}$ Proto jsou ad hoc anatematizovány také předměty domácího kultu prostřednictvím víceré zmínky „koňů“ stojících před chrámem, o kterých se nedozvídáme nic $\mathrm{v}$ dřívějších popisech vlád judských králů. Tento program měl své zárodky pravděpodobně již v době existence Judského království, ale takto vyhraněné požadavky jsou zaneseny retrospektivně jako ,realita“ do dějin až po pádu Jeruzaléma v roce 586 př. n. 1 .

Poslední sledované 6. stol. př. n. 1. je stoletím, kdy všechno „začalo“. Míněn je koncept monoteismu povstalý z dalekosáhlé reflexe porážky, pojaté jako důsledek zpronevěření se jahvistickému kultu. Tento koncept, který vzniká především $\mathrm{v}$ babylónské diaspoře $\mathrm{v}$ kruzích deportovaných elit, je pojat nábožensky, ale má i svoji zřetelnou politickou agendu (viz kritika Izraele jako konkurenta a kritika proasyrsky orientovaných judských králů Achaze a Menašeho). Uvedený retrospektivní ideový konstrukt napomáhá teologicky konceptualizovat dějiny jako zápas o pravou víru, jejíž esence je zanesena na samý prvopočátek v tom smyslu, že monoteismus je ještě starší než Izrael/Judsko samo. Stejný konstrukt má i své futurální sdělení, a sice že pouze monoteismus zajistí, že se minulost nebude opakovat. Hmotná kultura náboženské povahy podobné klíče k minulosti neposkytuje, protože dokládá reálné, co bylo, a nikoli programové a retrospektivní, jak to mělo být.

102 O. Keel - Ch. Uehlinger, Göttinen, Götter..., 394.

103 Thomas Römer, ,Zwischen Urkunden, Fragmenten und Ergänzungen: Zum Stand der Pentateuchforschung“, Zeitschrift für die alttestamentliche Wissenschaft 125/1, 2013, 2-24; Jan Christian Gertz (ed.), Grundinformation Altes Testament: Eine Einführung in Literatur, Religion und Geschichte des Alten Testaments, Göttingen: Vandenhoeck und Ruprecht 2006. 


\section{Shrnutí: Monoteismus jako nesamozřejmá reflexe dějinné krize}

Vzestup jahvismu jako výlučné podoby anikonického monoteismu v jižní Levantě byl procesem formovaným konkrétními politickými, ekonomickými, kulturními a náboženskými vlivy. Důležitou roli sehrály regionální interakce. Pro podobu monoteismu v Judsku je zásadní interakce s pelištejskou kulturou, při níž se na půdorysu pozdněkanaánské kultury utváří nová entita, která se až později, díky mnohačetným vlivům ze severu, z Izraele, stává zdokumentovatelnou územní politickou skutečností. Rovněž odtamtud přichází do Judska polyjahvistický kult, později centralizovaný, jehož anikonická a exkluzivně jahvistická forma je až výsledkem reflexe dějin započaté nejdříve na konci 7. stol. př. n. 1., akcelerované událostí pádu Jeruzaléma v roce 586 př. n. 1. a plně uskutečněné v 6. a 5. stol př. n. 1., tedy v době novobabylónské a perské. Nutno podotknout, že tento proces nelze chápat jako lineární, ireverzibilní a na všech místech, kde příslušníci Izraele žili, identický, jak dokládá například ještě delší dobu pokračující polyteistická a později polyjahvistická praxe judské komunity v egyptské Elefantině. ${ }^{104}$

104 K tomu viz O. Keel - Ch. Uehlinger, Göttinen, Götter..., 430-475. 


\section{SUMMARY}

\section{Monotheism in Israel and Judah among Archaeology, Text and Ideology: New Impulses, New Evidence, New Interpretations}

With the help of current archaeological results and by means of the reinterpretation of core textual traditions relating to the issue of cult, centralization, and monotheism, this study analyses the development of Jahvistic religion in Southern Levant with particular emphasis laid on interactions between Judah and its neighbouring territorial entities, Israel, Philistia and Moab. The author points out that a demonstrably aniconic form of monotheism was a reality only from the very final phasis of the existence of the Kingdom of Judah at the earliest and that the very concept of monotheism had been preceded by the idea of centralization adopted from the north, from the Omride dynasty ruling in the $9^{\text {th }}$ and early $8^{\text {th }}$ centuries BCE in Samaria. Though the close relation between Israel and Judah are concealed in a conventional reading and understanding of biblical texts, detailed analysis focused on the ideological decoding of these texts along with the use of archaeological data and the reading of other ancient textual sources results in a more complex image of religion in the region under consideration.

Keywords: monotheism; ideology; Southern Levant; archaeology; Kingdom of Judah; Israel; regional interactions.

Department of Old Testament Studies and

FILIP ČAPEK

Centre for Biblical Studies of Academy of Sciences

of Czech Republic

capek@etf.cuni.cz

Charles University

Černá 9

11555 Praha 1

Czech Republic 